DOI: $10.2478 /$ ausp-2014-0002

\title{
Surrealist Senses: Marcel Jean's Representations of Budapest
}

\author{
Imre József BALÁZS \\ Babeş-Bolyai University, Cluj-Napoca \\ Department of Hungarian Literary Studies \\ balazsimrejozsef@gmail.com
}

\begin{abstract}
The paper analyses the spatial representations and the selfrepresentations of the surrealist author Marcel Jean in his late autobiography entitled $A u$ galop dans le vent, where he reflects upon his life and upon the seven years that he spent in Budapest with his wife between 1939 and 1945, and also in his book Mnésiques, published in 1942 in Budapest. In this latter book the presence of the surrealist mythology of transformation can be interpreted as a representation of the dislocated self, Au galop dans le vent showing the historical and biographical contexts of these experiences.
\end{abstract}

Keywords: Marcel Jean, Árpád Mezei, European School, surrealism, war

\section{Marcel Jean and surrealism}

In September 1938 Marcel Jean, member of the Paris surrealist group, painter and poet present in the most important publications and exhibitions of the surrealists of those times, moves to Budapest with his wife, getting a job as a designer at a Hungarian textile company. Although they plan to stay no more than one or two years, their stay in Budapest will last for seven years-they are unable to return to France or to rejoin their surrealist friends in the United States during the war.

Marcel Jean was active as an artist in Budapest, several of his drawings of this period being now part of the Peggy Guggenheim collection in Venice. ${ }^{1}$ His textile designs created for the Francia-Magyar Pamutipar Rt. were deposited in the Museum of Applied Arts, in Budapest (Horváth 1992). He also published a book there in 1942 (Mnésiques, poetic essay with reproductions of 3 drawings of his own), and wrote another volume about Lautréamont's Maldoror during

1 The reproduction of 36 works by Marcel Jean and his biography can be accessed on the website of the Peggy Guggenheim Collection: http://www.guggenheim-venice.it/inglese/collections/ artisti/biografia.php?id_art=196 
the war years, his co-author being Árpád Mezei, essayist and future founder of the European School in Budapest (Jean and Mezei 1947). After his return to Paris, his cooperation with Mezei resulted later on in three more books: Genèse de la pensée moderne (Jean and Mezei 1950), Histoire de la peinture surréaliste (Jean and Mezei 1959) and a commented edition of the works by Isidore Ducasse / Lautréamont (Ducasse 1971). During his late years he also wrote an autobiography, $A u$ galop dans le vent (Jean 1991), of great interest for our analysis. About half of this book of 224 pages is a description of the Budapest years and the experience of the war, mixing elements of travel literature, of autobiographies, and having as a background the interaction and solidarity of people developed during the war.

This article analyses the descriptions of the city and the inner experience connected to this in two of Marcel Jean's books: Mnésiques and Au galop dans le vent. My purpose is also to analyse in a broader context the representations of Hungary and of Budapest in the autobiographical accounts.

\section{Marcel Jean's accounts of his seven years spent in Hungary}

Marcel Jean joined the surrealist group in 1933, and after this he participated in surrealist meetings, exhibitions and publications as a painter, poet, essayist and even actor. He earned his living as a textile designer, working for different factories in France and also in the United States. Being involved in the strikes of the designers and textile workers in Paris in 1936, and having become secretary of their craft union, in 1938 he was offered a job in Hungary, in the textile industry. As Jean recalls in his autobiography, those who offered him this job also hoped that after his departure from Paris, there would be less trouble in the unionist movement-at least from the employers' point of view (Jean 1991, 72-73). The offer seemed generous, and in September 1938 Jean left Paris with his newly wedded wife, Lily, planning to stay in Budapest for one year or two.

In Budapest, they lived in the Rózsadomb quarter, one of the most fashionable places in town, and they soon also began learning the Hungarian language. In July 1939 they spent their holidays in France, meeting André Breton, Yves Tanguy and Roberto Matta there. They soon returned to Hungary, Jean's contract being prolonged for another year. They did not presume that the war would prevent them from returning to France during the next years. In fact, Jean's Hungarian experience includes a period of seven years between September 1938 and May 1945, and also another visit to Budapest after the war. We can reconstruct his attitude towards this experience through his books and his correspondence.

First of all, I will try to identify Jean's strategies for integration into the Hungarian cultural space and society. Jean felt that the presence of a French 
couple in Budapest was quite rare at that time (80, single numbers refer to Jean 1991 further on), so their strategies for integration had to be worked out individually. They met several people who spoke French and who helped them grasp the basic elements of life in Hungary, but as Jean points out, most of them turned out to be Jews. Among the other middle-class people they met, only German could be considered as a widely spoken language (a language that the Jean family was not familiar with and did not really succeed in learning in spite of some language lessons), and in the Alföld where they also travelled, they met people who did not speak any other language besides Hungarian. Therefore, the majority of their contact persons were Jews, and this aspect became more and more important during the war years, although Jean describes himself as not particularly sensitive about this issue at the moment of arriving in Hungary. His comments on this aspect of origin are the following:

In France, we had never cared or even got any glimpse of the Jewish question, but in Hungary it had to be taken into account. [...] As most of the other inhabitants of the kingdom of Hungary, the Jews were patriots; they were talkative and humorous, among them many nonbelievers. They were very active in the country, they were everywhere: in liberal professions, in publishing, journalism and other intellectual circles, in the show business, industry, large and small businesses-so they permeated the population, reaching even the family of Horthy, the Head of State, whose wife had a Jewish great-grandmother ... [80, my translations - I. J. B. $]^{2}$

As we can see, Jean himself thinks of the national issue on a voluntary basis, seeing the nation as a community largely based upon the choice and the will to belong there. This is a view that will be contested more and more radically by the Hungarian realities during the next few years.

French was not the only language of communication though: both Lily and Marcel Jean attempted to learn Hungarian employing a private teacher, and Jean remembers Lily counting the steps descending from a hill in Hungarian (79-80). In his letters addressed to Árpád Mezei after his return to France, we can find occasionally Hungarian words or phrases, mostly in humorous contexts: "We hope you arrived safe and sound in your home country. [...] Zádor's writing is totally undecipherable for us-it seems that Hungarians try to revert to the

2 "En France, nous ne nous étions jamais souciés ni même aperçus de la question juive; en Hongrie elle se posait pourtant. [...] Comme la plupart des autres sujets du royaume de Hongrie, les Juifs étaient patriotes, loquaces et pleins d'humour; parmi eux, beaucoup d'incroyants. Cheville ouvrière des activités du pays, on les trouvait partout: professions libérales, édition, journalisme et cercles intellectuels, spectacles, industrie, grands et petits commerces, avaient imbriqués dans la population; jusqu'au régent Horthy, le chef de l'État, dont l'épouse avait une grande-mère juive..." 
Chinese ideogrammatic expression in writing. [phrase in Hungarian]. [...] Mabille was impressed when I read him your conference"3 (Jean to Mezei, 30 May 1948). We also know that Jean lectured in Hungarian after the war in the series of conferences organized by the European School in Budapest, on the topic of French surrealism (169).

Besides Hungarian language and friends who spoke French, one possible contact for Jean with the Hungarian world could have been art. However, he felt that his surrealist interests were not shared in the country: "I perceived no significant echo of Western movements, neither any activity of a real group of avant-garde. [...] The most 'advanced' painters stuck to German expressionism or Dutch abstractionism. Surrealism? Vaguely perceived, almost ignored, while in the Czech Republic, Serbia, Romania, it created its 'schools"'4 (80-81). He arrives to the same conclusion after meeting one of the few people whose interests roughly coincide with his: Árpád Mezei. They get into contact after the publication of Mnésiques, authentic surrealist blend of dream narratives, essays, poetry and drawings, a book inspired by a walk in the neighbourhood of the Schmidt castle in Óbuda, today the building of the Kiscelli Múzeum. Having read the book at one of their friends, Tamás Lossonczy the painter, Mezei gets fascinated with it, and they begin their discussions that will lead later on to several co-authored books and articles. Their first project, however, a sort of history of surrealism written for a Hungarian audience, initiated by Jean, has to be abandoned because of lack of resources. In Budapest they cannot find enough material to document this history in a professional manner:

We agreed to write an outline of the history of surrealism, to be published in Hungarian. We lacked documentation, however. In a bookshop, I came across a copy of Nadja, signed by Breton for the writer Marcel Sauvagehow this copy turned out to be there? (Breton could not tell me when, later in Paris, I told him about my discovery.) A bibliophile opened his library to me, it was a huge room lined with books from floor to ceiling where, in the domain of surrealism, I discovered the brochure Violette Nozières, which I had co-authored in 1935. Gyúla [sic] Illyés, writer and poet, very open and a real authority within the circles that we could call advanced, had known members of the Paris surrealist group. [...] He lent me some numbers of Surrealism in the Service of Revolution. But I could

3 "Nous espèrons que tu es arrivé sain et sauf dans ton pays natal. [...] A Zádor írása nekunk teljesen olvashatatlan - Úgy látszik, a magyarok az írásukban akarják visszatérni az ideogrammatic (kínai) íráshoz. [...] Mabille ‘sekre esett' quand je lui ai lu ta conférence, mise au point.”

4 "je ne perçus aucun echo significatif des mouvements occidentaux, aucune activité d'un véritable groupe d'avant-garde. [...] Les peintres les plus 'avancés' en étaient restés à l'expressionisme allemande ou à l'abstractionnisme néerlandais. Le surréalisme? Très vaguement perçu, presque ignoré, alors qu'en Tchéquie, Serbie, Roumanie, il faisait école." 
not get hold of Surrealist Revolution or Minotaur anywhere. The project of a history of surrealism was abandoned. ${ }^{5}(83-84)$

The lack of this type of material will not prevent them though from writing together an interpretation of Maldoror, where the kind of bibliography they use is more general, linked to psychology and philosophy.

In 1947, after his return to France, and after having seen some recent works by Hungarian painters, he will still think that Mezei's way of thinking is closest to what Jean considers to be surrealist: “There are no Hungarian surrealists-you're the only one of that curious species, until further notice"6 (Jean to Mezei, 11 April 1947). All these experiences suggest that for Marcel Jean art was not a very strong connecting tool to the Hungarian intellectuals, although he recounts meeting besides Mezei and Lossonczy poets like Gyula Illyés (84), Miklós Radnóti and István Vas (91), and also artists like Endre Rozsda and Lajos Barta (92). These contacts made Jean experiment later on with the promotion of Hungarian artists in France after the war, and also suggest the translation of some major French texts connected to surrealism-I shall return to this issue further on in my essay.

\section{Impressions of Hungary: differences that matter}

Our first impression of the Hungarian capital was olfactive-today all cities have the stale smell of pollution, but once each had its special aroma, Paris smelled of gasoline, London of coal, New York spreading the sweet smell of tar. Enclosed by huge campaigns, Budapest smelled like a farm, more exactly like horses. ${ }^{7}$ (79)

5 “On en vint à ébaucher le projet d'une histoire, ou d'un précis du surréalisme, à publier en hongrois. Nous manquions de documentation. Chez un bouquiniste, je tombai sur un exemplaire de Nadja dédicacé par Breton à l'écrivain Marcel Sauvage-comment cet exemplaire était-il arrivé là? (Breton ne sut me le dire lorsque, plus tard à Paris, je lui parlai de ma découverte.) Un bibliophile m'ouvrit sa bibliothèque, immense salle tapissée de livres du parquet au plafond où, en fait de surréalisme, il ne découvrit que la brochure Violette Nozières à laquelle j'avais collaboré en 1935. Gyúla [sic] Illyés, écrivain et poète, très ouvert et faisant autorité dans les cercles qui pouvaient se dire avancés, avait connu à Paris des membres du groupe surréaliste. [...] Il me prêta quelques numéros dépareillés du Surréalisme au service de la révolution. Nulle part, je ne pus mettre la main sur La Révolution surréaliste ou Minotaure. On abandonna le projet d'une histoire du surréalisme."

6 "Il n’y a pas des surréalistes hongrois—tu es le seul de cette curieux espèce, jusqu'à plus ample informé."

7 "Notre première impression de la capitale hongroise fut olfactive-aujourd'hui toutes les villes ont l'odeur fade de la pollution; autrefois chacune avait son arôme spécial, Paris sentait l'essence, Londres le charbon, New York répandait les effluves sucrés du goudron. Enserrée par d'immenses campagnes, Budapest sentait la ferme, plus exactement le cheval.” 
As we can see, Jean tries to recall his first impressions of Hungary through sensual effects. The scent associated with Budapest is a somewhat "rural" one; while the other cities Jean mentions are related to emblems of modern life, it is the horse that becomes Hungary's emblem in this paragraph, a creature denoting a more traditional culture, but also more mythical contexts. In this sense, Hungary seems to be a right place to experience the exotic.

The other memory recalling the first day of their stay in Budapest is a visual one: "Our second surprise was visual: shops displaying signs in a language completely incomprehensible for us" ${ }^{8}$ (79). Surrealists were great admirers of commercials and of different inscriptions displayed on the streets. They were looking for hidden meanings and connections between these signs, inscriptions and their own lives. For Jean, this strange and unintelligible nature of the inscriptions meant possibly also the fact that the hidden relationships between texts, images and everyday events seemed here impossible to discover at the time. This could be a reason why the strangeness, the alien character of the Hungarian language is represented in the text through a visual code, and not through an auditive experience for example.

At least two observations should be made regarding the representation of Jean's stay in Hungary: 1. the country is largely presented through its inhabitants-through people Jean gets in contact with; 2. while their first year in Budapest, the pre-war period is summed up in two and a half pages, the rest of this part (between pages 81-158) deals with the war years when they were trapped in Hungary, unable to leave the country. It is clear that this meant for Jean experiencing his limits, and also experiencing his talents to deal with extreme situations. Interesting enough, these are also the years when he creates his famous surrealist objects "arbre à tiroirs" [the tree of drawers] and "armoire surréaliste" [surrealist cabinet], considered by André Breton later on to be his masterpieces (82). The result of these two characteristics is that the focus of the narrative is quite rarely directed towards the inner side of the personality: Jean appears several times as a simple observer of the vivid life of the others-a sort of anthropologist who tries not to interfere decisively with the actions of others (although we know that he did interfere with the lives of others, even saving some lives during the war, more or less directly). In this sense, the text resembles a theatrical act where there are several characters, each of them spending only a few moments on stage. Because of the war, it is also a world turned upside down, with its tragic, comic and grotesque stories-Jewish boys entering Szálasi's youth organization for camouflage; Jean himself using his drawing skills to create his own baptism certificate to prove his non-Jewish origin; convinced communists taken away by the Russian army after the takeover of Budapest, while well-

8 "notre seconde surprise fut visuelle: les boutiques affichaient des enseignes dans une langue toute à fait incomprehensible." 
known "nyilas" activists carrying on with their lives in peace among the ruins of Budapest. The analogy of a theatrical performance is, therefore, valid also in this sense-of people playing roles of others, wearing masks, negotiating their parts within the play.

After more than a decade, Jean will develop his experiences connected to Hungarian people into a sort of Volksgeist-a humourous one, as one of his basic experience with Hungarians is telling jokes: "My long experience with the friendly people who over the centuries has become established on the site of the great Danubian plain helped me identify two of their main features, or at least of many of them. 1. They invented sealing wax. 2. They believe in Santa Claus"9 (Jean to Mezei, 1 July 1957). In fact, this is already a description of Hungarians' relationships with Western Europe-a caricature of their high hopes concerning their careers but also their expecting some kind of undefined help from Western people.

While in $A u$ galop dans le vent Jean insists very much on the outside events, on episodes connected to other people, the reverse of this attitude is shown in Mnésiques, where the inner experience of dreams and of visual associations has a much stronger presence. However, as I tried to prove in a former detailed analysis of Mnésiques, the basic characteristic of the representations of Hungarian landscapes is that inner and outside experiences are interchangeable in both directions within the text. We can recognize the ancient technique of mirroring inner feelings with nature and landscapes, but we see in Jean's book also the way desire can change a landscape or the way objects enter the dreams of the artist and become strong inner realities there. In this sense, the connection works both ways (Balázs 2013, 163).

In $A u$ galop dans le vent, the description of landscapes is less frequent, but there are two or three representations that seem quite important. One of them coincides with the more intensive description from the chapter Morphée from Mnésiques-description of the Schmidt castle:

In fact, [Schütz] Mihály and I spoke the same language, combining a certain disdain for conventions, a taste for the unusual and for the miracles encountered among the incidents of everyday life. One day he took us beyond the northern districts of the city, past an old cemetery, to a steep ramp along which there were shaky railings supporting some baroque cherubs made of rather deteriorated cement. This path led to a park with full size replicas of famous works of sculpture like Venus of Milo, Michelangelo's Moses, the Uffizi Porcellino, nymphs and antique vases

9 "Ma déjà longue expérience avec la sympathique population qui au cours des siècles s'est acclimatée sur le site de la grande plaine danubienne m'a permis de dégager deux traits principaux des dites indigènes, ou du moins de beaucoup d'entre eux. 1. Ils ont inventé la cire à cacheter; 2. Ils croirent au Père Noël." 
perched on mounds or sheltered by a fold of land, simulacra of simulacra, sometimes badly damaged. Alleys led to a masonry of the eighteenth century, shuttered, surrounded by other statues and broken sculptures. All this in abandonment. We could see no one.

An atmosphere of timeless disorder permeated the collection of fake relics. This crazy house was, said Mihály, the Schmidt castle, once the property of a curious antique collector. One morning in a room of the castle the body of his mysteriously murdered mistress was found.

This tour, along with memories and dreams that visited me at the time, made me write a book, Mnesics, published in 1942 by Editions Hungaria in Budapest, in French language. ${ }^{10}$ (82-83)

In Árpád Mezei's view, this description of ruins is in a way a premonitory one, coinciding with what Jean will see in Budapest after the bombings: "The castle and its surroundings appear in the dream as a desert of ruins, of fantastic dimensions. [...] Some years later, after the siege, looking out of the window of the writer's home in Buda, the sight was quite similar" (Mezei 1993a, 224-225, my translation, I. J. B.).

Other depictions include the sight of the bombing-where the sensational element is even caricatured. At the restaurant situated on János-hegy, where they go for a small excursion, the waiter greets them like this: "You came for the bombings, right?"11 (104). It seems that for some inhabitants of Budapest, the bombing of the city by the American air force became a habitual "show"something they had to get accustomed to, but also a sort of thrilling entertainment. Indeed, the "show" is described by Jean in terms of a theatrical performance ("the radio recited ritual litanies"; "like a theater curtain"; "on stage"

10 "En fait, [Schütz] Mihály et moi parlions la même langue, mêlant un certain dédain des conventions au goût de l'insolite et du merveilleux rencontrés parmi les incidents de la vie courante. Il nous conduisit un jour au-delà des quartiers nord de la ville, passé un vieux cimetière, jusqu'à une rampe abrupte bordée de balustrades chancelantes supportant quelques angelots de style baroque, moulages en ciment assez détériorés. Ce chemin menait vers un parc dénudé ou s'érigeaient les répliques grandeur nature d'oeuvres célèbres de la sculpture: Vénus de Milo, Moïse de Michel-Ange, le sanglier romain du musée des Offices, des nymphes et des vases antiques, perchés sur des monticules ou abrités par un pli de terrain, simulacres de simulacres parfois très abîmés. Des allées conduisaient à une batisse du XVIIIe siècle, volets clos, entourée d'autres statues et de débris de sculptures. Tout cela à l'abandon. On ne voyait personne.

Une atmosphère de désordre intemporel imprégnait la collection de faux vestiges. Cette demeure folle, c'était, nous dit Mihály, le château Schmidt, jadis domaine d'un antiquaire fantasque. Un matin, on avait trouvé, dans une salle du château, le corps de sa maitresse, mystérieusement assassinée.

De cette excursion et des souvenirs et rêves qui me visitèrent à cette époque, j'écrivis un récit, Mnésiques, publié en 1942 aux éditions Hungária à Budapest, en français."

"Vous venez pour les bombardements?" 
etc., 105). ${ }^{12}$ The metaphors stressing natural analogies might be interpreted as reflections of the ambiguous attitude of the viewer-watching the procession of forces that are beyond the control of everyday people resembles the effect of the sublime that can only be admired but cannot be interacted with. Jean describes the bombing using terms like "insects," "geysers," "clouds," “dragonflies” (105). These kinds of landscapes (just like the sight of the Schmidt castle surrounded by ruins) represent anxieties, uneasy feelings, the only way of overcoming these being (in 1942 at least, in Mnésiques, before the bombings and before the siege of Budapest) the core of surrealist mythology: love. In Mnésiques, the landscape with mountains is represented at a certain moment as a female profile, and the sight of the ruins of the Schmidt castle becomes the place of a revelation, and not a mere visual image any more (Balázs 2013, 159).

During his stay in Hungary, Marcel Jean travels also in Transylvania on at least two occasions, and makes a business trip also to Bucharest. It is interesting to notice that in the representations of Transylvania he uses the same pattern as in the depiction of the bombing-animal and natural analogies. But this time the animals are mythological beasts or quite strange creatures like the Transylvanian variant of water buffaloes that is not a familiar sight for a Frenchman:

The horizons of the Székely country, which I have contemplated for the first time, evoked to me nostalgic memories of a previous life that I had spent in the large plains at the foot of the high Carpathians, and, without ever having seen them, I seemed to recognize their bluish profiles. [...] The mountain was like a witch's cauldron and it would not have seemed surprising to find in a clearing these ladies celebrating a Sabbath. [...] The water buffaloes, black and ugly as dragons from fables, pulled chariots, ancestors of covered wagons that transported the emigrants of the last century from Central Europe and from elsewhere across the savannas of the American West. ${ }^{13}$ (86-87)

This could suggest that Jean considered Transylvania as a more archaic land, connected to primordial existence-this representation being quite frequent also among Hungarian people of the period. The American analogy also stresses the

12 "la radio récitait les litanies rituelles;" "comme un rideau de théâtre;" "sur la scène"

13 "Les horizons du pays Székely, pour moi qui les contemplais pour la première fois, évoquaient comme le souvenir nostalgique d'une existence antérieure que j'aurais passée dans ces grandes plaines douces étendues au pied des hautes Carpates dont, sans les avoir jamais vues, il me semblait reconnaître les profils bleutés. [...] La montagne était comme un chaudron de sorcières et il n'eût pas paru surprenant de rencontrer dans une clairière ces dames en train de célébrer quelque sabbat. [...] Des buffles, noirs et hideux comme les dragons des fables, tiraient des chars bâchés, ancêtres des covered waggons qui transportèrent au siècle passé les émigrants d'Europe centrale et d'ailleurs à travers les savanes de l'Ouest américain." 
'wild' character of the Transylvanian land that seems to offer itself for explorers. Besides the reference to the American frontier experience, another element that suggests this idea is the reference to wild berries that Jean and his friends could collect in seemingly unmeasurable quantities (87). We should notice also the reference to the profile of the mountains and the salted lakes-the mythology of Jean's series of drawings called Profile de la Memoire, being present also in Mnésiques, can be linked to the image of the mountains that seemed strangely well-known for the painter.

Another trip to Szilágysomlyó and its surroundings with Árpád Mezei and his wife is an opportunity for Jean also to discover the multiethnic aspects of Transylvania. The discovery of diversity is mirrored through architectural and gastronomical experiences:

The population was half Hungarian, half Romanian-among Romanians the custom was building blue houses and they were cooking using oil, while living side by side, the Hungarians, oh economic determinism, had whitewashed houses and they cooked using fat-and the two communities had different costumes. ${ }^{14}(87)$

The trip to Bucharest, carried out also in 1941, is recalled much later in the book, on the occasion of their return to France in 1945 via Bucharest and Istanbul. Jean's impressions about Bucharest are those of familiarity—good quality French being spoken there, and the atmosphere of the textile industries, of the great boulevards resembling boulevard Haussmann, the fashionable cars, cafés and the "Latin" vivacity of the inhabitants make him feel comfortable there among friends with surrealist connections-like the family members of Victor Brauner whom they meet in Bucharest (147). During their transit to Istanbul they cannot revive the same atmosphere-in the post-war situation Bucharest seems to them quite affected by the war, too. But the way the Bucharest memories are inserted into the narrative (a flashback to 1941 within a narrative concerning events from 1945) suggests that the Romanian capital is for Jean a mirror of Paris, a visual substitute for his home-the 1941 memories serving as anticipation of their return to Paris.

14 "La population, mi-hongroise, mi-roumaine, badigeonnait chez les Roumains les maisons en bleu et faisaient la cuisine à l'huile tandis que, vivant du même sol et côte à côte, les Hongrois, ô déterminisme économique, avaient des maisons blanchies à la chaux et cuisinaient à la graisse, et les deux communautés portaient des costumes différents." 


\section{Cultural transfers between France and Hungary}

One of the closest friends of Jean among the members of the surrealist group was Yves Tanguy, with whom he also exchanged several letters. When Jean's wife met Tanguy's family in Paris in 1939, they must have exchanged some kind of small gifts. Tanguy's message written after this occasion shows that Jean tried to identify the elements of Hungarian identity also through specific meals and drinks, and distributed these among his friends: "Your dear Tokaji vanished quickly."15 Tanguy also drew a sketch about the bottle of Tokaji, in his very specific style (Tanguy 1993 [29 April 1939], 17).

After the outbreak of the war, Tanguy moved to the United States with his future wife Kay Sage, and tried to help his friends, among them Marcel Jean, to escape Europe. One of his letters shows that these attempts were blocked by several bureaucratic and financial impediments:

We tried many things and spoke with many people about you so far, alas to no avail. Because according to the new laws the person who gives an affidavit must formally commit to ensure a certain amount of money per month to the beneficiary, and also has to fully commit himself to bear the expenses in case of a disease. There are 15 things like that each of them as bad as this. We found an old lady who initially had promised this thing, but when she read all this she just deflated. ${ }^{16}$ (Tanguy 1993 [30 April 1941], 25)

After his return to Paris, Jean was quite active in transferring Hungarian culture to France, but also in the opposite way, transferring valuable pieces of information for Árpád Mezei and his fellow founders of the European School in Budapest. Jean was a contact person for the young artists Béla Bán and Endre Bálint who finally managed to exhibit their works at the 1947 international surrealist exhibition. In Paris he tried to promote major artists like Tivadar Csontváry or Lajos Vajda, showing their works to André Breton and othersBreton seeming quite interested in Csontváry, but uncontent with the quality of the reproductions that Jean showed them. The quality of the reproductions also delayed the publication of Jean's and Mezei's article about Csontváry very much, which finally appeared in les Cahiers d'Art (Jean and Mezei 1949).

15 "Ton cher petit Tokay a disparu allègrement."

16 "Nous avons essayé beaucoup de choses et gens pour toi jusqu'ici hélas sans résultat. Car d'après les nouvelles lois la personne qui donne un affidavit doit s'engager formellement à garantir une certaine somme d'argent par mois au bénéficiaire, s'engager également à l'avoir entièrement lui et sa famille à sa charge en cas de maladie. Il y a comme ça 15 choses aussi terribles les unes que les autres. Nous avions trouvé une vieille dame qui avait promis, mais quand elle a lu ça elle s'est tout simplement dégonflée." 
In the opposite direction, he followed closely the activity of the European School, making suggestions for translations (from Jarry, Breton and others), also lecturing on his return to Budapest about the recent evolutions of surrealist painting and becoming honorary member of the European School. He suggested to Mezei several contacts among the surrealists with whom the European School could cooperate, and largely contributed to the visibility of Mezei's works within the French cultural field. However, the political context made it more and more difficult to keep in touch with his friend and co-author, and after the publication of Genèse de la pensée moderne in 1950, their contacts became more sporadic. Histoire de la peinture surréaliste, begun following the same pattern of cooperation between Jean and Mezei as the previous books, was quite difficult to finish with no real possibility of cooperation in the context of the Hungarian Stalinist regime where contacts with France were watched with suspicion by the authorities. Jean felt that the amount of work carried out documenting the later stages of surrealism and of the international diffusion of surrealist art made the book his own in a greater proportion than the previous ones-this is why this volume has as its author Marcel Jean on its cover and in the bibliographies, "avec la collaboration de Arpad Mezei." Although Mezei accepted this formula in a letter written to Jean in 1959, after the publication of Au galop dans le vent he tried to highlight some aspects of Jean's narrative that seemed to him a retroactive distortion of the nature of their cooperation (Mezei 1993b).

In his study about Hungarian surrealism, Marc Martin is right to observe that the presence of Hungarian painting is quite scarce in Histoire de la peinture surréaliste, and considers that Jean could have written much more about Hungarian surrealism in this book precisely because of his detailed knowledge about the situation of Hungarian art and about the European School: "Back in Paris, he did not contribute to the spreading of Hungarian avant-garde in France (e.g. The History of Surrealist Painting, published by Seuil in 1959, although written in collaboration with Árpád Mezei [... ] does not contain any articles or comments on the Hungarian painting)" ${ }^{17}$ (Martin 1995, 66). Possible reasons for this omission include the ambivalent relationship of Hungarian painters to surrealism. From the letters of Béla Bán and Endre Bálint addressed to Imre Pán and Árpád Mezei we know about the project of some young Hungarian artists to create a group that would be programmatically surrealist. However, this project was soon abandoned precisely by the painters who took part at the 1947 international surrealist exhibition (Bán 1990 [1947], 131). Therefore, although Hungarian painting had strong connections to surrealist art during the 1940s,

17 "De retour à Paris, il ne contribua pas davantage à la diffusion française de l'avant-gardisme hongrois (par exemple son Histoire de la peinture surréaliste, parue au Seuil en 1959, et pourtant pensée et rédigée en collaboration avec Àrpàd Mezei, [...] ne comporte aucun article ou commentaire sur la peinture hongroise)." 
no actual surrealist group was constituted there, and this is a notable difference between the Hungarian, the Romanian and the Czech art scenes. In the latter two countries, as Jean also noticed in his book of memories, surrealism flourished within a dynamic group activity. In this sense, Jean's Histoire (if it were published a decade later) most probably would have included only painters like Simon Hantai, Endre Rozsda, Judit Reigl, who actually lived in Paris after the Second World War, and were valued by André Breton during the late stages of surrealism.

Another reason for the omission of Hungarian painters may have been the fact that Jean saw Hungarian culture as centered more on literature.

"It does not surprise me that the Hungarians of Paris have sent nothing surrealist to your show. There are no Hungarian surrealists-you're the only one of that curious species, until further notice."18 (Jean to Mezei, 11 April 1947); "I think that historically the Hungarians are at their best in poetry and philosophy rather than in the arts, but I think this means no prejudice to the possible painters, but I do not know enough about them to give a precise opinion about them. As for Rozsda and Barta, they seemed at the time sufficiently distant from surrealism, but this does not mean that they cannot naturally grow in this direction." ${ }^{19}$ (Jean to Mezei, 12 May 1947).

\section{Conclusions}

Marcel Jean comes closest to Hungarian culture in his 1942 book Mnésiques, where he sees inner and outside phenomena as interchangeable, as communicating. As I have shown in another essay, Mnésiques is a book where we can see the presence of the surrealist mythologies of transformation and of the hybrid-the latter one being also an emblem of a dynamic, unstable identity. Au galop dans le vent offers a background for these experiences, looking back on past events from a historical perspective, where the outside events become more important. Jean offers an image of his Hungarian experience through presenting meetings with people, through some visual elements-and generally through sensual aspects. The image of Budapest under siege prevails in the narrative, marking a decisive period of Jean's identity-and showing elements of the characteristic urban

18 “Je ne m'étonne pas que les Hongrois du Paris n’aient rien envoyé de surréaliste pour ton exposition. Il n'y a pas des surréalistes hongrois-tu es le seul de cette curieux espèce, jusqu'à plus ample informé."

19 "Je crois d'ailleurs que historiquement les Hongrois se révèlent plutôt dans la poésie et la philosophie que dans les arts plastiques, ceci naturellement ne préjuge en sien de peintres possibles, mais je ne connais pas suffisamment eux dont tu me parles pour donner un avis làdessus. Quant à Rozsda et Barta, ils me semblaient à l'époque, assez éloignés du surréalisme, cela ne veut pas dire naturellement qu'ils ne puissent se développer dans cette direction?” 
mythology of the surrealist prose written by Breton or Aragon (Bancquart 2004, Ottinger 2002). This urban mythology, however, of Au galop dans le vent is only a distant echo of Nadja or Le paysan de Paris, and even of the one of Jean's own Mnésiques, and it needs further investigation.

\section{Works cited}

Balázs Imre József. 2013. Francia álombeszéd Budapestről: Marcel Jean Mnésiques címú könyve. [Dreamspeech about Budapest: Mnésiques by Marcel Jean.] In Kortárs magyar kisebbségi irodalmak. [Contemporary Hungarian Minority Literatures.], ed. Imre József Balázs, 152-164. Kolozsvár: Egyetemi Múhely Kiadó. Bancquart, Marie-Claire. 2004. Paris des Surréalistes. [The Paris of Surrealists.] Paris: Éd. de la Différence.

Bán Béla Pán Imréhez. [Letter from Bán Béla to Pán Imre.] 1990 [1947]. In Péter György and Gábor Pataki, Az Európai Iskola és az Elvont Múvészek csoportja. [The European School and the Group of Abstract Artists.] Budapest: Corvina.

Ducasse, Isidore comte de Lautréamont. 1971. Oeuvres complètes commentées par Marcel Jean et Arpad Mezei. [Complete Works Commented by MJ and AM.] Paris: Eric Losfeld.

Horváth Hilda. 1992. Marcel Jean textiltervei a Francia-Magyar Pamutipar Rt számára. [The Textile Designs of MJ for the Francia-Magyar Pamutipar Rt.] In Ars decorativa 12, ed. Gyula Rózsa, 141-150. Budapest: Iparmúvészeti Múzeum.

Jean, Marcel avec la collaboration d' Arpad Mezei. 1959. Histoire de la peinture surréaliste. [The History of Surrealist Painting.] Paris: Seuil.

Jean, Marcel et Arpad Mezei. 1947. Maldoror. Paris: Éd. du Pavois.

—. 1949. Csontvary. Cahiers d'Art (June): 89-98.

—. 1950. Genèse de la pensée moderne. [The Genesis of Modern Thought.] Paris: Éd. Corrêa.

Jean, Marcel to Árpád Mezei. Correspondence. Budapest: Országos Széchényi Könyvtár, Kézirattár, Fonds Árpád Mezei.

Jean, Marcel. 1942. Mnésiques: Essai avec trois dessins de l'auteur. [Mnesics : Essay with Three Drawings by the Author.] Budapest: Editions Hungária.

—. 1991. Au galop dans le vent. [Galloping through the Wind.] Paris: Ed. JeanPierre de Monza.

Martin, Marc. 1995. L’infortune du surréalisme en Hongrie. [The Misfortune of Surrealism in Hungary.] Mélusine vol. XV: 45-74.

Mezei Árpád. 1993a. A francia szürrealista költészet. [French Surrealist Poetry.] In Árpád Mezei, Mikrokozmoszok és értékelések. [Microcosms and Evaluations.], 217-226. Pécs: Jelenkor. 
—. 1993b. Marcel Jean: Au galop dans le vent. In Árpád Mezei, Mikrokozmoszok és értékelések. [Microcosms and Evaluations.], 300-304. Pécs: Jelenkor.

Ottinger, Didier. 2002. Surréalisme et mythologie moderne. Les voies du labyrinthe d'Ariane à Fantômas. [Surrealism and Modernist Mythology : The Ways of the Labyrinth from Ariadne to Fantômas.] Paris: Gallimard.

Tanguy, Yves. 1993. Lettres de loin: à Marcel Jean. [Letters from Far Away : to MJ.] Paris: Le Dilettante. 